\title{
Biomedical and Pharmaceutical Applications of Inductively Coupled Plasma-Mass Spectrometry (ICP- MS)
}

\author{
Desam Nagarjuna Reddy, \\ Abdul Jabbar Al-Rajab and \\ Gowkanapalli Ramachandra Reddy \\ Additional information is available at the end of the chapter
}

http://dx.doi.org/10.5772/intechopen.74787

\begin{abstract}
Medical science is a field of study that is relevant to all people, but the development of pharmaceutical, biomedical and life science is of particular importance. In these fields, further studies are being established to determine with incredible accuracy the quantities and concentration of inorganic elements and organic compounds, such as nucleotides, sulphur and phosphorous containing peptides and proteins, to be used in all kinds of drugs. Since 1980, inductively coupled plasma-mass spectrometry (ICP-MS) has emerged as a new and powerful technique for elemental and isotopic analysis. It provides a means for the analysis of an extremely wide range of elements and the co-analysis of most elements in the periodic table. It can also be used for qualitative, quantitative and semiquantitative analysis and for the measurement of isotopic ratios through mass-to-charge ratios. In recent years, ICP-MS has emerged as the best technique for the quantification of inorganic impurities in pharmaceutical and biomedical applications. This chapter focuses on introducing the applications of ICP-MS in the pharmaceutical and biomedical fields. Some problems facing ICP-MS are also presented at the end of this chapter.
\end{abstract}

Keywords: pharmaceutical analysis, biomedical analysis, inductively coupled plasma-mass spectrometry (ICP-MS)

\section{Introduction}

Within the field of pharmaceuticals, two fundamental issues are necessary for drug therapy: safety and efficiency. The impact of elemental impurities in drugs must be investigated using 
pharmacological and toxicological profiles so that the safety requirements and dosage forms of bulk drug scan be determined. This is vital because unwanted pharmacological and toxicological effects may result from elemental impurities and improper drug dosage forms. As such, all products intended for human consumption must be characterised as completely as possible to ensure quality and safety and to ensure that elemental impurities are being monitored and controlled. Thus, pharmaceutical analysis is one of the most important activities related to ensuring the safety of drugs [1].

\subsection{Heavy metals in drugs}

During the synthesis of pharmaceuticals, inorganic impurities can result from several different sources and phases, including solvents, raw materials, reagents, catalysts, electrodes, reaction vessels, plumbing and other equipment used. These impurities are often a result of the manufacturing process. Routinely monitored as impurities in several drugs are cadmium, copper, chromium, mercury, iridium, molybdenum, nickel, osmium, lead, tungsten, palladium, platinum, rhodium, and ruthenium and vanadium and their derivatives [2]. For the synthesis of many pharmaceuticals, tungsten-containing catalysts are used in the intermediate reaction process. In the pharmaceutical industry, monitoring heavy metals is an important activity for both reaction intermediates and final drug substances, not only because of their ability to catalyse decomposition but also because of their potential for toxicity. Even at very low doses, heavy metals such as lead, cadmium, mercury and chromium pose a serious health risk when used for pharmaceutical purposes [3]. Long exposures can cause physiological and behavioural issues. For instance, daily exposure to $0.06 \mathrm{mg}$ of lead for a period of 1 month is sufficient to cause long-term problems such as kidney impairment, demineralization and obstructive lung disease. In pharmaceutical and biomedical substances, the presence of heavy metals is monitored and limited by regulatory authorities. Tests are performed to ensure that no inorganic-based reagents or contaminates are introduced into the drugs at any step during the manufacturing process. The determination of residues of metal catalysts and reagents has moved increasingly into the focus of regulatory guidance within the last 5 years [4]. The European medicines agency has published guidelines on the specification requirements for inorganic metal catalysts and reagents [5]. The United States Pharmacopoeia (USP), British Pharmacopoeia (BP), European Pharmacopoeia (EP) and Japanese Pharmacopoeia (JP) have proposed the collective monitoring of the total metal content in pharmaceutical products. For example, the EP has proposed a limit of $20 \mu \mathrm{g} / \mathrm{g}$ of platinum in calcium folinate. In aqueous solutions, metal sulphide precipitation results in a clear visual difference of colour, but this are not the case for similarly treated standard metal solutions. In both cases, determining the exact presence of heavy metals is a process that is time consuming and not selective, specific or accurate. Thus, there is a great need to develop a highly sensitive and more selective technique to determine the presence of heavy metals in pharmaceutical substances and, accordingly, to ensure the safety and efficacy of drugs intended for human consumption.

\subsection{Atomic spectrometric techniques used in pharmaceutical and biomedical analysis}

Spectrophotometric techniques are widely used for trace elemental analysis, including atomic absorption spectrophotometer (AAS), inductively coupled plasma-atomic emission 


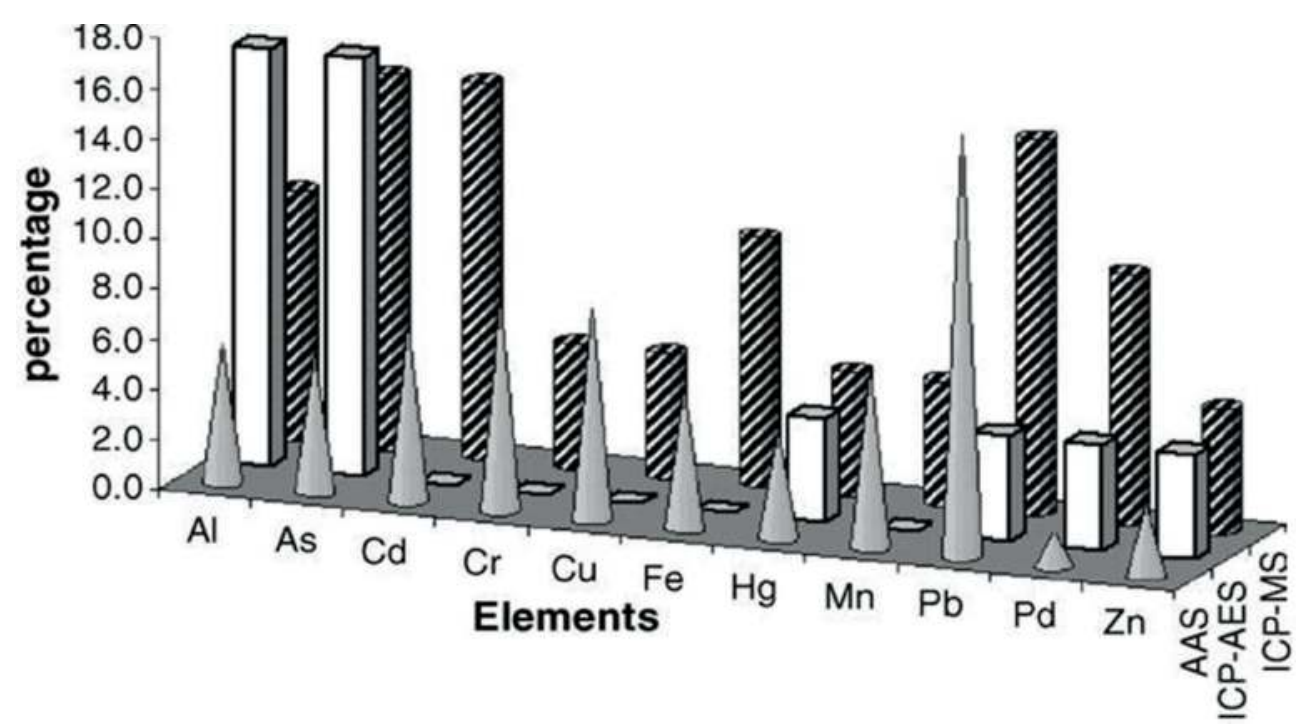

Figure 1. Usage pattern of different spectrophotometric techniques in detection of trace metals in drugs and pharmaceutical industry.

spectrophotometer (ICP-AES) and inductively coupled plasma-mass spectrometry (ICP-MS) $[3,6]$. AAS is used extensively, often for analysing different samples. Flame-AAS (F-AAS) or low graphite furnace (GF-AAS) is used for samples with a high concentration of metals. Because of its high detection limit, the application of this technique to the analysis of impurities is limited. However, each metal present can be individually analysed to a high level of specificity because of the hollow-cathode lamp used.

ICP-AES is an important technique for the trace elemental analysis of pharmaceutical samples $[7,8]$. While it is a powerful technique for multielemental analysis, it does suffer from spectral interferences and low levels of accuracy. At present, ICP-MS has emerged as the most powerful, sensitive and selective technique for the determination of elemental impurities in trace and ultra-trace concentrations in pharmaceutical and bulk drug substances. Hence, ICP-MS provides a major service to the pharmaceutical and bulk drug industries in allowing them to identify and quantify elemental impurities. However, there are limitations to ICP-MS in that it is very expensive and lacks certified reference standards for most drugs and pharmaceutical products. The pattern of the various spectrometric techniques used recently is shown in Figure 1.

\section{Principle and instrumentation of ICP-MS}

The hyphenated ICP-MS principle and construction are essentially identical. Plasma employs the ionisation source for the ICP, and positively charged ions detect the mass analyser in the mass spectrometer (MS). Generally, argon gas is used to generate plasma at a high frequency (30 MHz), with energy in the range of 1000-2000 W, since in the periodic table most elements 
excite and ionise at plasma temperatures in the range of $6000-10,000 \mathrm{~K}$. The torch is made with quartz and consists of three concentric tubes through which the argon flows. The periodic table shown in the Figure 2 makes multielemental analysis possible. A schematic diagram of the ICP-MS instrumentation is shown in Figure 3.

When a sample is introduced into the plasma, it goes through desolvation, vaporisation, atomisation and ionisation before entering the mass analyser. There are many methods for introducing the samples, which can be solid, liquid or gas, into the plasma. Most commonly, liquid samples are introduced using pneumatic nebulization.

From ICP, the MS extracts the ions at a low pressure, via sampling and skimmer cones. Later, ions travel towards the quadrupole mass analyser through a series of ion lenses. Positively charged ions are then separated according to the mass-to-charge ratio. Ions can then be detected by an electron multiplier and amplified. The quadrupole mass analyser is widely used ICP-MS, and the double-focusing field mass analyser is used to achieve more separation and to decrease isobaric interference (such as ${ }^{40} \mathrm{Ar}^{35} \mathrm{Cl}^{+}$interference with ${ }^{75} \mathrm{As}^{+}$). A speciation analysis can also be performed using time-of-flight mass spectrometry (TOFMS). Another possible separation technique, the introduction of samples into the source of ICP at atmospheric pressure makes its possible of coupling separation techniques to ICP-MS. This decreases the isobaric overlap of the high-resolution mass analyser and interests ions with different massto-charge ratios differently via chemical reaction. The percentages of the different elements analysed by ICP-MS in pharmaceutical substances and bulk drugs are shown in Figure 4.
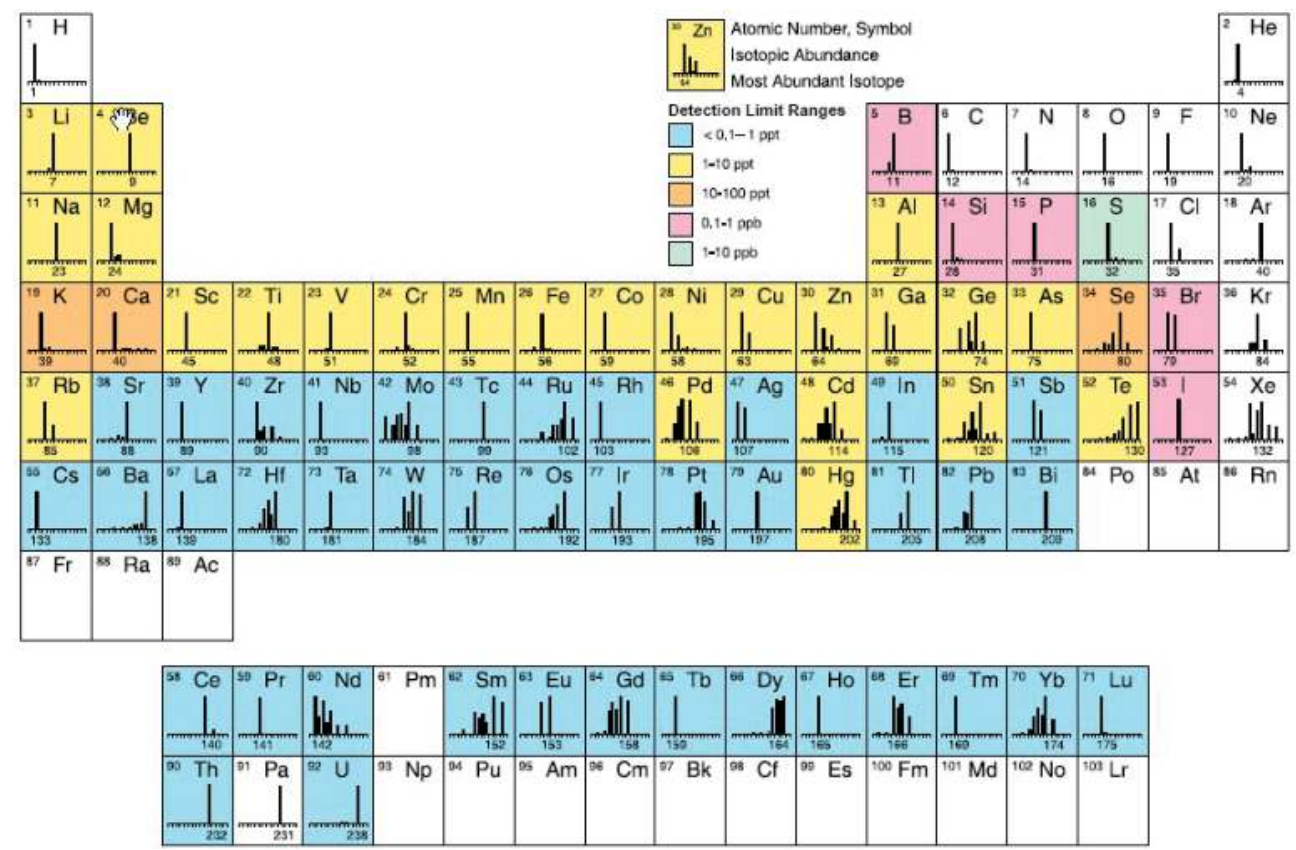

Figure 2. Elements detectable by ICP-MS analysis. 


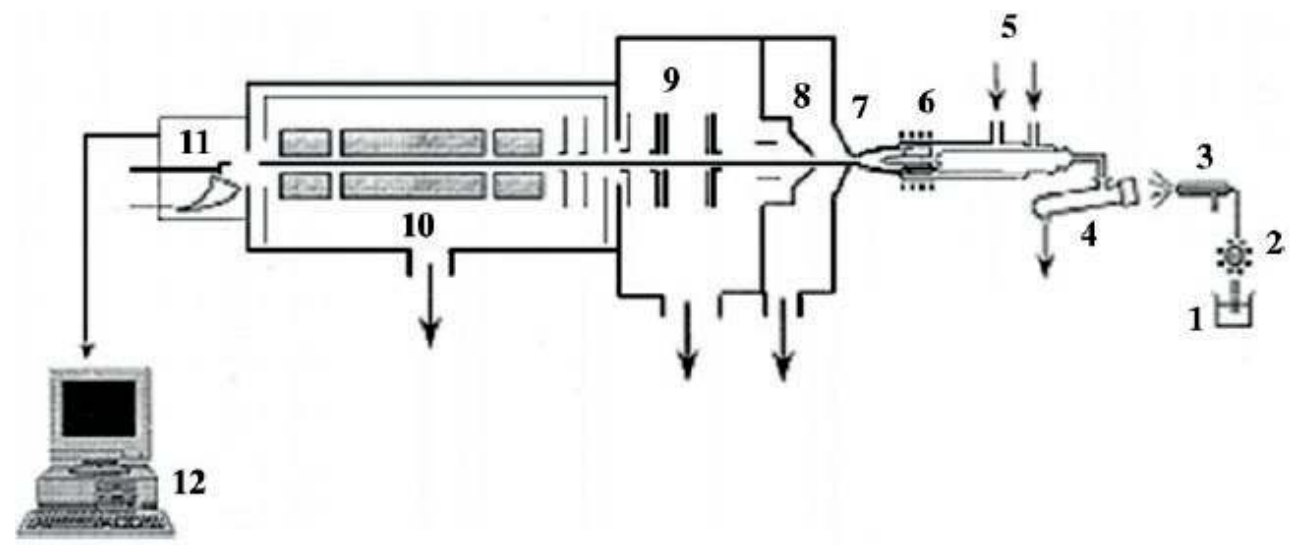

Figure 3. Schematic diagram of inductively coupled plasma-mass spectrometer: 1. Liquid sample, 2. Pump, 3. Nebuliser, 4. Spray chamber, 5. Argon gas torch inlets, 6. Torch, 7. Sampler cone, 8. Skimmer cone, 9. Ion lenses, 10. Quadrupole mass analyser, 11. Electron multiplier detector, and 12. Data collection.

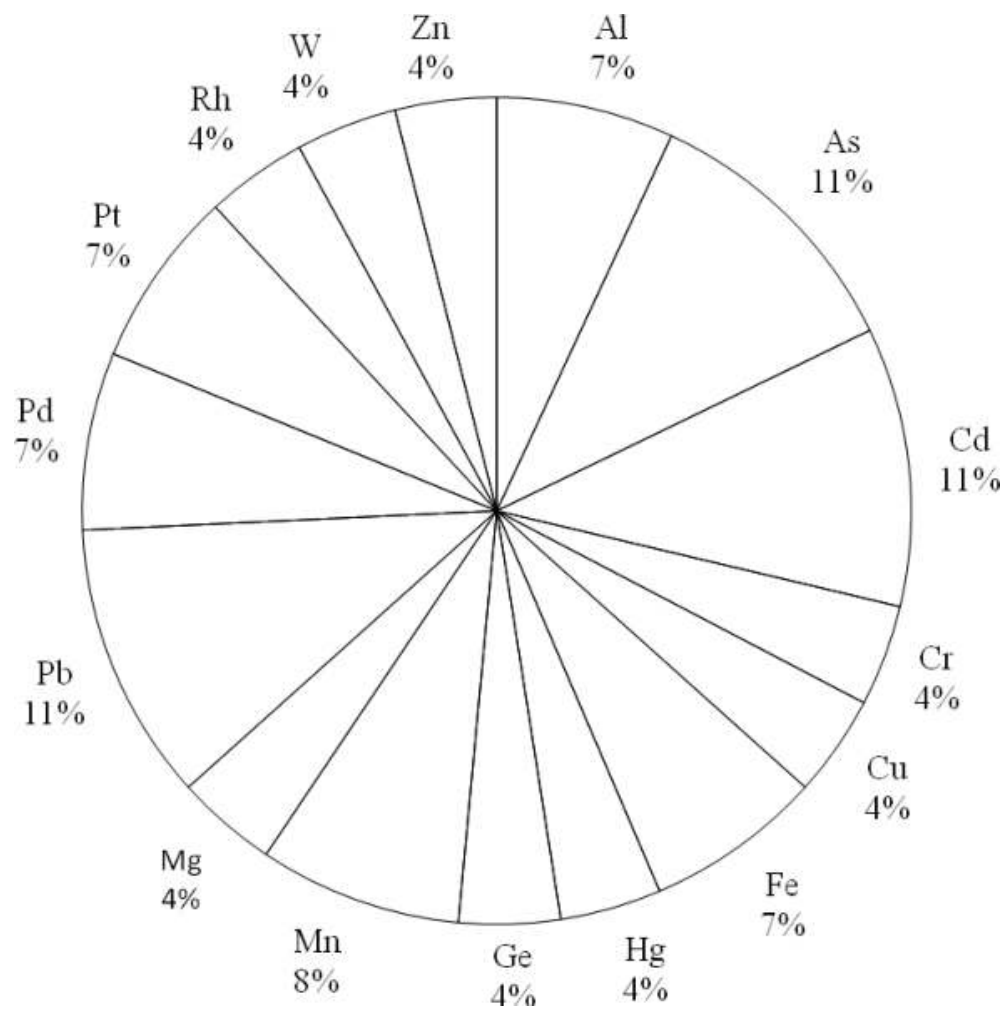

Figure 4. Individual elements analysed by ICP-MS in pharmaceutical substances and bulk drugs. 


\section{Sample preparations}

Samples are normally prepared using dissolution or digestion with a low concentration of mineral acids $[9,10]$. For the reproducibility of volatile, low-concentration and low-volume elements, microwave digestion is better than acid digestion. However, microwave digestion and acid digestion are both appropriate for pharmaceutical samples due to the volatility of some metals and trace detection limits. The laser ablation technique [11] can be used for solid samples. Some of the sample preparation methods are summarised in Table 1.

\begin{tabular}{|c|c|c|c|c|c|}
\hline Element & $\begin{array}{l}\text { Bulk drug/ } \\
\text { formulation }\end{array}$ & Procedure & Medium & Calibration $^{\mathrm{a}}$ & Reference \\
\hline W & Bulk drugs & Dissolution & $80: 20(\mathrm{v} / \mathrm{v}) \mathrm{HNO}_{3}$ & $\begin{array}{l}\text { EC with }{ }^{209} \mathrm{Bi} \\
\text { for IS }\end{array}$ & [12] \\
\hline $\mathrm{Fe}$ & Methotrexate & $\begin{array}{l}\text { Microwave- } \\
\text { assisted }\end{array}$ & $\mathrm{H}_{2} \mathrm{SO}_{4}+\mathrm{HNO}_{3}$ & EC with ${ }^{56} \mathrm{Fe}$ & [13] \\
\hline \multirow[t]{3}{*}{$\mathrm{Pd}, \mathrm{Pt}, \mathrm{Rh}$} & Enalapril maleate & Dissolution & 1:1 $\mathrm{HNO}_{3^{\prime}} 0.3 \mathrm{M}$ & \multirow{3}{*}{$\begin{array}{l}\text { EC with In } \\
\text { for IS }\end{array}$} & \multirow[t]{3}{*}{ [14] } \\
\hline & Calcium folinate & Dissolution & \multirow{2}{*}{$\begin{array}{l}0.2 \mathrm{M} \mathrm{HNO}_{3^{\prime}} 0.2 \mathrm{M} \\
\mathrm{HNO}_{3}\end{array}$} & & \\
\hline & Levodopa & Dissolution & & & \\
\hline $\mathrm{Pd}$ & Fosinopril sodium & Dissolution & $\begin{array}{l}25 \%(v / v) 2 \text {-butoxy } \\
\text { ethanol and water }\end{array}$ & $\begin{array}{l}\text { EC with In } \\
\text { for IS }\end{array}$ & [15] \\
\hline 69 elements & $\begin{array}{l}\text { Drug substances, } \\
\text { intermediate and } \\
\text { raw materials }\end{array}$ & $\begin{array}{l}\text { Dissolution, } \\
\text { sonication }\end{array}$ & $80 \%(\mathrm{v} / \mathrm{v}) \mathrm{HNO}_{3}$ & $\mathrm{EC}$ & [16] \\
\hline \multirow[t]{2}{*}{$\mathrm{Cr}, \mathrm{Ni}, \mathrm{Sn}, \mathrm{Pb}$} & \multirow[t]{2}{*}{ Vitamin E } & $\begin{array}{l}\text { Microwave } \\
\text { digestion }\end{array}$ & \multirow[t]{2}{*}{$\begin{array}{l}\mathrm{HNO}_{3}+\mathrm{H}_{2} \mathrm{O}_{2^{\prime}} \\
\text { Triton X + Tetralin }\end{array}$} & \multirow[t]{2}{*}{$\begin{array}{l}\mathrm{EC}, \mathrm{Y}, \mathrm{In} \text { and } \\
\mathrm{Tl} \text { for IS }\end{array}$} & \multirow[t]{2}{*}{ [17] } \\
\hline & & $\begin{array}{l}\text { Emulsion } \\
\text { preparation }\end{array}$ & & & \\
\hline $\mathrm{Na}, \mathrm{Br}, \mathrm{Pd}, \mathrm{Ba}, \mathrm{I}$ & $\begin{array}{l}\text { Methamphetamine } \\
\mathrm{HCl}\end{array}$ & Dissolution & $\mathrm{H}_{2} \mathrm{O}$ & $\mathrm{EC}$ & [18] \\
\hline $\begin{array}{l}\text { As, Se, Mo, Ru, Pd, Cd, In, } \\
\text { Sn, Sb, Pt, Hg, Bi, Ag. }\end{array}$ & $\begin{array}{l}\text { API with various } \\
\text { functionalities }\end{array}$ & Dissolution & $\begin{array}{l}\text { 2-butoxy ethanol/ } \\
\text { water }(25: 75 \mathrm{v} / \mathrm{v})\end{array}$ & $\begin{array}{l}\text { EC with } \mathrm{Co} \text {, } \\
\text { Au and } \mathrm{Rh} \\
\text { for IS }\end{array}$ & [19] \\
\hline $\begin{array}{l}\mathrm{Cr}, \mathrm{Cu}, \mathrm{Mg}, \mathrm{Mn}, \mathrm{Mo}, \mathrm{P} \\
\mathrm{Se}, \mathrm{Zn} \text {. }\end{array}$ & $\begin{array}{l}\text { Multimineral and } \\
\text { multivitamin }\end{array}$ & $\begin{array}{l}\text { Microwave } \\
\text { digestion }\end{array}$ & $\mathrm{HNO}_{3}$ & $\begin{array}{l}\text { EC with Co } \\
\text { for IS }\end{array}$ & [20] \\
\hline $\begin{array}{l}\mathrm{Li}, \mathrm{B}, \mathrm{V}, \mathrm{Cr}, \mathrm{Mn}, \mathrm{Ni}, \mathrm{Zn}, \mathrm{Cu} \\
\mathrm{Br}, \mathrm{Sr}, \mathrm{Sn}, \mathrm{Ba}, \mathrm{Pt} \text {, and } \mathrm{Pb}\end{array}$ & Ecstasy tablets & Dissolution & $1 \%(\mathrm{v} / \mathrm{v}) \mathrm{HNO}_{3}$ & $\begin{array}{l}\text { EC with Rh } \\
\text { for IS }\end{array}$ & [21] \\
\hline \multirow{4}{*}{$\begin{array}{l}\mathrm{Ti}, \mathrm{Cr}, \mathrm{Mn}, \mathrm{Fe}, \mathrm{Co}, \mathrm{Ni}, \mathrm{Cu}, \\
\mathrm{Zn}, \mathrm{Cd}, \mathrm{Hg}, \mathrm{Pb}\end{array}$} & Dicyclomine $\mathrm{HCl}$, & \multirow{4}{*}{$\begin{array}{l}\text { Dissolution } \\
\text { and digestion }\end{array}$} & $5 \%(\mathrm{v} / \mathrm{v}) \mathrm{HNO}_{3}$ & \multirow[t]{4}{*}{$\mathrm{EC}$} & \multirow[t]{4}{*}{ [22] } \\
\hline & Ethambutol, & & $\mathrm{HNO}_{3}+\mathrm{H}_{2} \mathrm{O}_{2}+\mathrm{H}_{2} \mathrm{O}$ & & \\
\hline & Pyrazinamide, & & & & \\
\hline & Furazolidone & & & & \\
\hline As, $\mathrm{Cd}, \mathrm{Hg}, \mathrm{Pb}$ & $\begin{array}{l}\text { Dietary } \\
\text { supplements }\end{array}$ & $\begin{array}{l}\text { Microwave } \\
\text { digestion }\end{array}$ & $\mathrm{HNO}_{3}$ & $\begin{array}{l}\text { Ec with Rh, IN } \\
\text { Lu, Bi for IS }\end{array}$ & [23] \\
\hline
\end{tabular}

${ }^{\mathrm{a} E C}$ : external calibration; IS: internal standardisation.

Table 1. Sample preparations procedures for analysis of trace elements in pharmaceutical substances and bulk drugs using ICP-MS. 


\section{Applications}

\subsection{Applications of ICP-MS in pharmaceutical samples}

\subsubsection{Determination of multielements in drugs and pharmaceutical substances}

Supplements in the form of gluconate contained the lowest concentration of cadmium, which was detected in many zinc supplements, according to ICP-MS [26]. In calcium supplements, cadmium and lead were detected using ICP-MS, F-AAS and electrothermal-atomic absorption spectroscopy (ETAAS) [27]. Using GF-AAS and inductively coupled plasma-optical emission spectroscopy (ICP-OES), iron and palladium were detected in the bulk drug methotrexate; and the results were compared which obtained from ICP-MS [13]. To avoid polyatomic interferences before quadrupole mass analysis (such as ${ }^{40} \mathrm{Ar},{ }^{16} \mathrm{O}$ with ${ }^{56} \mathrm{Fe}$ ), hexapole collision cell was used. Using ICP-MS, lead and its isotope ratio was investigated in antacids and calcium drug supplements using rhenium as an internal standard [28-30].

Tungsten has been identified in bulk drug substances and their intermediates, with bismuth used as an internal standard [31]. With the help of different isotopes, spectral interferences have been monitored in bulk drug substances. In bulk drug samples, ICP-MS was also used to detect up to $2500 \mathrm{ppm}$ of tungsten [31]. The ICP-MS results are in accordance with those of microwave induced plasma-mass spectrometry (MIP-MS). Hence, ICP-MS has been used for the expeditious screening for inorganic impurities such as rhodium, palladium, platinum, beryllium, vanadium, manganese, cobalt, nickel, copper, zinc, molybdenum, cadmium, tin, thorium and lead, using $\mathrm{Rh}^{103}, \mathrm{Pd}^{105}, \mathrm{Pd}^{106}, \mathrm{Pt}^{195}$ and In isotopes as an internal standard.

\subsubsection{Multielements in synthetic drugs}

Sodium, bromine, palladium, barium and indium have been investigated in methamphetamine hydrochloride, which is prepared using catalyst and reagent methods [18]. Barium, palladium, bromine, iodine and sodium were detected by Emeds and Nagais using ICP-MS. The levels of these elements in N-methylamphetamine were measured, and the results were compared with neutron activation analysis (NAA). ICP-MS has been used to detect multielements in synthetic drugs; these elements include arsenic, selenium, cadmium, indium, tin, antimony, lead, bismuth, silver, palladium, platinum, mercury, molybdenum, and ruthenium. Several ICP-MS procedures have been reported for performing single and multielemental analysis in drugs and pharmaceutical substances, as shown in Table 2.

\subsubsection{Multielements in herbal drugs}

In herbal drugs such as dietary supplements, inorganic impurities are a major concern due to their major toxicity and impurities (e.g., As, $\mathrm{Cd}, \mathrm{Hg}$ and $\mathrm{Pb}$ ) [23]. Normally, dietary supplements are analysed using high-resolution ICP-MS. Microwave digestion method is also an accepted method according to National Institute of Standards and Technology (NIST) reference materials. 


\begin{tabular}{|c|c|c|c|c|}
\hline Drug/formulations & Elements & MDL & Detector & Reference \\
\hline $\begin{array}{l}\text { Dicyclomine } \\
\mathrm{HCl} \text {, Ethambutol, } \\
\text { Pyrazinamide, }\end{array}$ & $\begin{array}{l}\mathrm{Ti}, \mathrm{Cr}, \mathrm{Mn}, \mathrm{Fe}, \mathrm{Co} \\
\mathrm{Ni}, \mathrm{Cu}, \mathrm{Zn}, \mathrm{Cd} \\
\mathrm{Hg}, \mathrm{Pb}\end{array}$ & Not reported & Varian ultramass 700 & {$[22]$} \\
\hline \multicolumn{5}{|l|}{ Furazolidone } \\
\hline Neusilin & $\mathrm{Al}, \mathrm{Mg}$ & 40 and $6 \mu \mathrm{g} / \mathrm{g}$ & $\begin{array}{l}\text { Laser ablation system: CETACLSX-100, } \\
\text { Perkin-Elmer SCIEX, ELAN } \\
\text { 6000ICP-MS }\end{array}$ & {$[23]$} \\
\hline $\begin{array}{l}\text { Drug substances, } \\
\text { intermediate and } \\
\text { raw materials }\end{array}$ & 69 Elements & $0.004-19$ ppm & $\begin{array}{l}\text { Elan } 6000 \text { ICP-MS, } 1300 \text { Wrf, cross } \\
\text { flow nebuliser, Scott spray chamber }\end{array}$ & [16] \\
\hline Vitamin E & $\mathrm{Cr}, \mathrm{Ni}, \mathrm{Sn}$ and $\mathrm{Pb}$ & $\begin{array}{l}3.02,0.22,2.92 \\
0.07 \mathrm{ppb} \text { (emulsion) } \\
0.13,0.05,0.70 \\
0.08 \mathrm{ppb}\left(15 \% \mathrm{HNO}_{3}\right)\end{array}$ & $\begin{array}{l}\text { Aglient } 7500 \text { ICP-MS, } 1100 \text { Wrf } \\
\text { Meinhard nebuliser }\end{array}$ & [17] \\
\hline $\begin{array}{l}\text { Methamphetamine } \\
\mathrm{HCl}\end{array}$ & $\mathrm{Na}, \mathrm{Br}, \mathrm{Pd}, \mathrm{Ba}, \mathrm{I}$ & Not reported & $\begin{array}{l}\text { Seiko ICP-MS SPQ-6100, } 1.35 \mathrm{~kW} \\
\text { quadrupole }\end{array}$ & [18] \\
\hline $\begin{array}{l}\text { Fosinopril sodium } \\
\text { (monopril) }\end{array}$ & $\mathrm{Pd}$ & $0.1 \mu \mathrm{g} / \mathrm{g}$ & $\begin{array}{l}\text { Plasma Quad PQ11 Turbo plus ICP-MS } \\
\text { jacketed Scott type spray chamber, } \\
\text { cooled to } 5^{\circ} \mathrm{C} \text {, platinum sample cone }\end{array}$ & {$[15]$} \\
\hline $\begin{array}{l}\text { Enalapril maleate, } \\
\text { calcium folinate, } \\
\text { levodopa }\end{array}$ & $\mathrm{Pd}, \mathrm{Pt}, \mathrm{Rh}$ & $15,2.8,2.5 \mathrm{ng} / \mathrm{g}$ & $\begin{array}{l}\text { Plasma Quad II STE peristaltic pump: } \\
\text { spray chamber: double pass, water } \\
\text { cooled }\left(10^{\circ} \mathrm{C}\right)\end{array}$ & {$[14]$} \\
\hline API & $\begin{array}{l}\text { As, Se, Mo, Ru, } \\
\text { Pd, Cd, In, Sn, Sb, } \\
\text { Pt, Hg, Bi, Ag. }\end{array}$ & $\begin{array}{l}0.37,0.42,0.08,0.2, \\
0.18,0.03,0.17,0.35 \\
0.16,0.03,1.82,1.51 \\
0.15 \mu \mathrm{g} / \mathrm{g}\end{array}$ & $\begin{array}{l}\text { VG Plasma Quad PQII TURBO plus, } \\
\text { ICP-MS and Micro mass platform } \\
\text { ICP-MS }\end{array}$ & [19] \\
\hline $\begin{array}{l}\text { Multimineral and } \\
\text { multivitamin }\end{array}$ & $\begin{array}{l}\mathrm{Cr}, \mathrm{Cu}, \mathrm{Mg}, \mathrm{Mn} \\
\mathrm{Mo}, \mathrm{P}, \mathrm{Se}, \mathrm{Zn}\end{array}$ & $\begin{array}{l}48.3,47.1,24.3,9.0 \\
43.2,750,24,109 \mathrm{ng} / 1\end{array}$ & VG Plasma Quad 3 ICP-MS, 1380 W & {$[20]$} \\
\hline Methotrexate & $\mathrm{Fe}$ & $0.2 \mu \mathrm{g} / \mathrm{g}$ & $\begin{array}{l}\text { Thermo elemental ICP-MS with } \\
\text { collision cell technology }\end{array}$ & {$[13]$} \\
\hline $\begin{array}{l}\text { Bulk drug } \\
\text { substances }\end{array}$ & W & $0.04 \mathrm{ppm}$ & $\begin{array}{l}\text { Perkin-Elmer Elan } 6000 \text { ICP-MS, AS-91 } \\
\text { auto sampler 1300rf }\end{array}$ & [12] \\
\hline Ecstasy tablets & $\begin{array}{l}\mathrm{Li}, \mathrm{B}, \mathrm{V}, \mathrm{Cr}, \mathrm{Mn}, \\
\mathrm{Ni}, \mathrm{Zn}, \mathrm{Cu}, \mathrm{Br}, \mathrm{Sr} . \\
\mathrm{Sn}, \mathrm{Ba}, \mathrm{Pt} \text {, and } \mathrm{Pb}\end{array}$ & Not reported & $\begin{array}{l}\text { Perkin-Elmer SCIEX Elan } 6000 \\
\text { ICP-MS, Gibson peristaltic pump, } \\
\text { rf1000W, nebuliser ryton cross flow } \\
\text { with gem tips }\end{array}$ & [21] \\
\hline $\begin{array}{l}\text { Dietary } \\
\text { supplements }\end{array}$ & As, $\mathrm{Cd}, \mathrm{Hg}, \mathrm{Pb}$ & $8.2,18,140,25 \mathrm{ng} / 1$ & $\begin{array}{l}\text { Micro mass Plasma Trace-2 HR } \\
\text { ICP-MS, rf1350W }\end{array}$ & {$[23]$} \\
\hline $\begin{array}{l}\text { Chinese medicinal } \\
\text { material }\end{array}$ & As, $\mathrm{Hg}$ & $0.19,0.32 \mu \mathrm{g} / 1$ & $\begin{array}{l}\text { ELAN } 6000 \text { ICP-MS rf } 1000 \mathrm{~W}, \mathrm{HP} \\
4500 \mathrm{ICP}-\mathrm{MS} \text { rf } 1200 \mathrm{~W} \text {, Babington } \\
\text { type cross flow nebuliser, peristaltic } \\
\text { pump, double pass spray chamber }\end{array}$ & {$[24]$} \\
\hline $\begin{array}{l}\text { Dietary } \\
\text { supplements }\end{array}$ & $\begin{array}{l}\mathrm{Pb}, \mathrm{Hg}, \mathrm{Cd}, \mathrm{As}, \mathrm{U} \\
\mathrm{Cr}, \mathrm{V}, \mathrm{Cu}, \mathrm{Zn}, \mathrm{Mo} \\
\mathrm{Pd}, \mathrm{Sn}, \mathrm{Sb}, \mathrm{Tl}, \mathrm{W}\end{array}$ & Not recorded & $\begin{array}{l}\text { Micro mass platform ICP-MS } \\
\text { Meinhard concentric nebuliser }\end{array}$ & {$[25]$} \\
\hline
\end{tabular}

Table 2. Determination of single and multielements in drugs and pharmaceuticals using ICP-MS. 
An analysis of arsenic and mercury in Chinese Medicinal Materials (CMM) was completed using ICP-MS, with trace amounts of both arsenic and mercury found [24]. This is notable because of the leaching characteristics of these elements. Mercury and arsenic are often used in traditional Chinese medicine (TCM) and have insoluble sulphides due to the low leaching efficiency of the cinnabar or realgar minerals in the drug formulations [24]. ICP-MS has been used to determine elemental impurities in plant and dietary materials, [25] and indium has been used as an internal standard.

In herbal materials, quality and safety is of major importance. Lead, arsenic and cadmium, in particular, are of considerable importance in herbal materials such as mineralised mint, nettle and black-wrack leaves [32]. In herbal materials, arsenic, cadmium and lead have been quantitatively determined to be in the range $0.2-200 \mathrm{ppb}, 0.1-20 \mathrm{ppb}$ and $0.1 \mathrm{ppb}-10 \mathrm{ppm}$, respectively. Also, arsenic was investigated in uncoated TCM using ICP-MS with high-pressure microwave digestion [33].

\subsection{Application of ICP-MS in biomedical analysis}

The continuous improvement of techniques and their applications in the life sciences sphere, including the combining of organic and inorganic MS, has helped to further advance the field. For inorganic MS and life sciences, ICP-MS has emerged as a key technique in biomedical research. In this section, some of the applications of ICP-MS in the biomedical field will be explored.

\subsubsection{Analysis of DNA using ICP-MS}

The development of cancer cells and modifications in DNA are commonly caused by the chemical modification of nucleobases, such as styrene oxide. The detection of cancer and DNA adducts is essential, and there are various methods based on standard reference materials, such as mass spectrometry, ${ }^{31} \mathrm{P}$ labelling and immunoassays (however, these are not readily available as they have not been made for three decades). The problem is that identification and unknown modification is not possible. Such problems as selectivity, sensitivity, and qualitative and quantitative technique soften arise when using internal standards, regardless of their structure.

For example, ICP-MS quantitatively engages phosphorus signals in modified nucleotides using bis(4-nitropenyl)phosphate (BNNP) as an internal standard [34, 35]. Hence, ICP-MS has independent elemental selectivity, sensitivity and detection capability.

\subsubsection{Analysis of proteins using ICP-MS}

In recent years, ICP-MS was used extensively in the field of proteomics [36] for the determination of metal concentrations in proteins and biomedical analysis. In these studies, similarly, bromine was detected quantitatively in rats and human plasma metabolism using ICP-MS [36]. In biological systems, and especially in proteins, metals play an important role as cofactors. Without proteins, there will be an absence of essential metals such as manganese, iron, copper, cobalt, molybdenum and zinc and of essential non-metals such as selenium and iodine. 
A deficiency in these metals and non-metals cause diseases as well as catalytic cytotoxic reactions. The field of proteomics determines the metals contained in proteins and, therefore, faces the challenging task of identifying metals and their concentrations, which requires a more selective, sensitive and powerful analytical technique. ICP-MS has been used to identify phosphorus, iron, zinc and copper quantitatively within brain proteins and has been used in the study of neurodegenerative diseases $[37,38]$. ICP-MS also represents a powerful technique for the detection of copper, iron and zinc in proteins in the study of Alzheimer's disease and has also analysed copper, zinc and iron with respect to ${ }^{54} \mathrm{Fe} /{ }^{55} \mathrm{Fe},{ }^{65} \mathrm{Cu} /{ }^{63} \mathrm{Cu}$ and ${ }^{67} \mathrm{Zn} /{ }^{64} \mathrm{Zn}$.

\subsubsection{Analysis of trace elements in human health}

Everybody knows that in human health, some of the elements are essential and others are toxic. However, the benefits and risks of each element depend on the quantity of the intake, the accumulation, the mobility of the element, the storage and interaction of the element in metabolites, the oxidation number, the metal-ligand ratio and the complexity of its interaction with different elements. ICP-MS has become one of the most powerful techniques for elemental speciation studies. In HepG2 cell and liver cell lines, copper and its isotope ratio ${ }^{63} \mathrm{Cu} /{ }^{65} \mathrm{Cu}$ has been measured accurately using ICP-MS [39], and in human blood and livers, iron and its isotopic ratio has been measured. In the liver, iron and its isotopic composition has been found to be higher than that of the blood and muscles [40].

In vivo, many essential and non-essential elements can interact with each other. Because of these interactions, it is important to anticipate deficiency and excess and to know elemental toxicity levels. To use elemental analysis to determine concentrations, ICP-MS has proved to be an advantageous technique. ICP-MS has been used to identify trace elements that are toxic and those that are essential [41-44]. In human blood and serum, many trace elements can be found, including cobalt, copper, zinc, selenium, rubidium, rhodium, palladium, cadmium, tungsten, platinum, mercury, thallium and lead. Both blood and serum selenium correlated with blood can contain the trace elements lead, mercury, copper and zinc.

\section{Brief solution to problems in the application of ICP-MS}

ICP-MS is a good analytical method when compared to the other analytical methods available. However, it is not without its drawbacks. These include signal fluctuation and the matrix effect, which occurs when elements that are very close in terms of mass number experience an indistinguishable influence [45]. The matrix effect might be a result of the plasma, the deposition of salts in the orifices, ion extraction or the internal standard [46]. The matrix effect can cause severe interference, but it can be eliminated by selecting a matching standard for the matrix of the isotope being diluted or by ensuring a greater dilution of the specimen. It can be of particular concern for double electric charge ions, such as barium and cerium, as these elements have low second ionisation energy levels. Oxides can be controlled by elevating the temperature of the plasma or slowing the rate of flow. Polyatomic ions and isobars can impede the detecting the mass-to-charge ratio via quantitative analysis, making them very important to analysts. 


\section{Conclusion}

ICP-MS has the power required to sensitively analyse the presence of trace elements; the method has low detection limits, allows for more selectivity of elemental mass, provides insight into the isotope ratio and performs ultra-trace elemental detection. It can be used for the elemental analysis of inorganic and organic elements in all kinds of drugs, including nucleotides, sulphur, and phosphorus containing proteins, providing both a qualitative and quantitative determination with accuracy, making it a vital method for trace element analysis in the pharmaceutical and biomedical fields.

\section{Author details}

Desam Nagarjuna Reddy ${ }^{1 *}$, Abdul Jabbar Al-Rajab ${ }^{1}$ and Gowkanapalli Ramachandra Reddy ${ }^{2}$

*Address all correspondence to: dndnrchem@gmail.com

1 Centre for Environmental Research and Studies, Jazan University, Jazan, Saudi Arabia

2 Department of Polymer Science and Technology, College of Science, Sri Krishnadevaraya University, Anatapur, AP, India

\section{References}

[1] Nageswara Rao R, Kumar Talluri MVN. An overview of recent applications of inductively coupled plasma-mass spectrometry (ICP-MS) in determination of inorganic impurities in drugs and pharmaceuticals. Journal of Pharmaceutical and Biomedical Analysis. 2007;43:1-13

[2] Wang T, Walden S, Egan R. Development and validation of a general non-digestive method for the determination of palladium in bulk pharmaceutical chemicals and their synthetic intermediates by graphite furnace atomic absorption spectroscopy. Journal of Pharmaceutical and Biomedical Analysis. 1997;15:593-599

[3] Bings NH, Bogaerts A, Broekaert JAC. Atomic spectroscopy. Analytical Chemistry. 2006;78:3917-3946

[4] Wollein U, Bauer B, Habernegg R, Schramek N. Potential metal impurities in active pharmaceutical substances and finished medicinal products - A market surveillance study. European Journal of Pharmaceutical Sciences. 2015;77:100-105

[5] Elemental Impurities-Limits (Chapter 232), 2014. Pharm. Forum 40, USP, Elemental Impurities-Procedures (Chapter 233), Pharm. Forum 40, USP; 2014

[6] Beauchemin D. Inductively coupled plasma mass spectrometry. Analytical Chemistry. 2006;78:4111-4136 
[7] Stoica AL, Peltea M, Baiulescu GE, Ionica M. Determination of cobalt in pharmaceutical products. Journal of Pharmaceutical and Biomedical Analysis. 2004;36:653-656

[8] Wang L, Marley M, Jahansouz H, Bahnck C. Determination of content uniformity and distribution characteristics of an investigational drug in its tablets dosage form and granule by ICP-AES. Journal of Pharmaceutical and Biomedical Analysis. 2003;33:955-961

[9] Montaser A, editor. Inductively Coupled Plasma Mass Spectrometry. 1st ed. New York: Wiley-VCH; 1998

[10] Jarvis I. Hand Book of Inductively Coupled Plasma Mass Spectrometry. Glasgow and London: Blackie. pp. 172-224

[11] Gunther D, Hattendorf B. Solid samples analysis using laser ablation inductively coupled plasma mass spectrometry. Trends in Analytical Chemistry. 2005;24:255-265

[12] Wang T, Ge Z, Wu J, Li B, Liang AS. Determination of tungsten in bulk drug substance and intermediates by ICP-OES and ICP-MS. Journal of Pharmaceutical and Biomedical Analysis. 1999;19:937-943

[13] Niemela M, Kola H, Eilola K, Peramaki P. Development of analytical methods for the determination of sub-ppm concentrations of palladium and iron in methotrexate. Journal of Pharmaceutical and Biomedical Analysis. 2004;35:433-439

[14] Lasztity A, Kelko-levai A, Varga I, Zih-Perenyi K, Bertalan E. Development of atomic spectrometric methods for trace metal analysis of pharmaceuticals. Microchemical Journal. 2002;73:59-63

[15] Lewen N, Schenkenberger M, Larkin T, Conder S, Brittain H. The determination of palladium in fosinopril sodium (momopril) by ICP-MS. Journal of Pharmaceutical and Biomedical Analysis. 1995;13:879-883

[16] Wang T, Wu J, Hartman R, Jia X, Egan RS. A multi element ICP-MS survey method as an alternative to the heavy metals limit test for pharmaceutical materials. Journal of Pharmaceutical and Biomedical Analysis. 2000;23:867-890

[17] Ponce de Leon CA, Montes-Bayan M, Caruso JA. Trace element determination in vitamin E using ICP-MS. Analytical and Bioanalytical Chemistry. 2002;374:230-234

[18] Kishi T. Journal of Research of the National Bureau of Standards (USA). 1988;93:469-471

[19] Lewen N, Mathew S, Schenkenberger M, Raglione T. A rapid ICP-MS screen for heavy metals in pharmaceutical compounds. Journal of Pharmaceutical and Biomedical Analysis. 2004;35:739-752

[20] Soltyk K, Lozak A, Ostapczuk P, Fijalek Z. Determination of chromium and selected elements in multimineral and multivitamin preparations and in pharmaceutical raw material. Journal of Pharmaceutical and Biomedical Analysis. 2003;32:425-432

[21] Suzuki S-I, Tsuchihashi H, Nakajima K, Matsushita A, Nagao T. Analyses of impurities in methamphetamine by inductively coupled plasma mass spectrometry and ion chromatography. Journal of Chromatography. A. 1988;437:322-327 
[22] Murty ASRK, Kulshresta UC, Rao TN, Talluri MVNK. Determination of heavy metals in selected drug substances by inductively coupled plasma-mass spectrometry. Indian Journal of Chemical Technology. 2005;12(2):229-231

[23] Dolan SP, Nortrup DA, Bolger PM, Capar SG. Analysis of Dietary. Supplements for arsenic, cadmium, mercury, and lead using inductively coupled plasma. Mass Spectrometry. Journal of Agricultural and Food Chemistry. 2003;51:1307-1312

[24] Wu XH, Sun DH, Zhuang ZX, Wang XR, Gong HF, Hong JX, Lee FSC. Analysis and leaching characteristics of mercury and arsenic in Chinese medicinal material. Analytica Chimica Acta. 2002;453:311-323

[25] Raman P, Patino LC, Nair MG. Evaluation of metal and microbial contamination in botanical supplements. Journal of Agricultural and Food Chemistry. 2004;52:7822-7827

[26] Krone CA, Wyse EJ, Ely JTA. Cadmium in zinc-containing mineral supplements. International Journal of Food Sciences and Nutrition. 2001;52:379-382

[27] Bourgoin BP, Boomer D, Powell MJ, Willie S, Edgar D, Evans D. Instrumental comparison for the determination of cadmium and lead in calcium supplements and other calcium-rich matrices. Analyst. 1992;117:19-22

[28] Amarasiriwardena D, Sharma K, Barnes BM. Fresenius. Journal of Analytical Chemistry. 1998;362:493-497

[29] Scelfo GM, Flegal AR. Lead in calcium supplements. Environmental Health Perspectives. 2000;108:309-313

[30] Wolf RE. Analysis of lead in antacids and calcium supplements. Atomic Spectroscopy. 1997;18:169-174

[31] Okoro H, Fatoki O, Adekola F, Ximba B, Snyman R, Opeolu B. Human exposure, biomarkers, and fate of organotins in the environment. Reviews of Environmental Contamination and Toxicology. 2011;213:27-54

[32] Soltyk K, Fijalek Z. Inductively-coupled plasma mass spectrometric (ICP-MS) and graphite-furnace atomic absorption spectrometric (GF-AAS) determinations of arsenic, cadmium and lead impurities in medical herbal raw materials. Analytical Chemistry. 2000;45:879-886

[33] Ong E-S, Yong Y-L, Woo S-O. Determination of arsenic in traditional Chinese medicine by microwave digestion with flow injection-inductively coupled plasma mass spectrometry (FI-ICP-MS). Journal of AOAC International. 1999;82:963-967

[34] Siethoff C, Feldmann I, Jakubowski N, Linscheid MJ. Quantitative determination of DNA adducts using liquid chromatography/electrospray ionization mass spectrometry and liquid chromatography/high resolution inductively coupled plasma mass spectrometry. Journal of Mass Spectrometry. 1999;34:421-426

[35] Edler M, Jakubowski N, Linscheid M. Styrene oxide DNA adducts: Quantitative determination using 31P monitoring. Analytical and Bioanalytical Chemistry. 2005;381:205-211 
[36] Axelsson BO, Jornten-Karlsson M, Michelsen P, Abou-Shakra F. The potential of inductively coupled plasma mass spectrometry detection for high-performance liquid chromatography combined with accurate mass measurement of organic pharmaceutical compounds. Rapid Communications in Mass Spectrometry. 2001;15:375-385

[37] Beauchemin D, Kisilevsky R. A method based on ICP-MS for the analysis of Alzheimer's amyloid plaques. Analytical Chemistry. 1998;70:1026-1029

[38] Becker JS, Zoriy M, Pickhardt C, Przybylski M, Becker JS. Investigation of Cu-, Zn- and Fe-containing human brain proteins using isotopic-enriched tracers by LA-ICP-MS and MALDI-FT-ICR-MS. International Journal of Mass Spectrometry. 2005;242:135-144

[39] Fosset C, McGaw BA, Reid MD, McArdle HJ. A non-radioactive method for measuring $\mathrm{Cu}$ uptake in HepG2 cells. Journal of Inorganic Biochemistry. 2005;99:1018-1022

[40] Walczyk T, Blanckenburg FV. Deciphering the iron isotope message of the human body. International Journal of Mass Spectrometry. 2005;242:117-134

[41] Barany E, Bergdahl IA, Bratteby LE, Lundh T, Samuelson G, Schutz A, Skerfving S, Oskarsson A. Relationships between trace element concentrations in human blood and serum. Toxicology Letters. 2002;134:177-184

[42] Muller ALH, Oliveira JSS, Mello PA, Muller EI, Flores EMM. Study and determination of elemental impurities by ICP-MS in active pharmaceutical ingredients using single reaction chamber digestion in compliance with USP requirements. Talanta. 2015;136:161-169

[43] Støving C, Jensen H, Gammelgaard B, Stürup S. Development and validation of an ICP-OES method for quantitation of elemental impurities in tablets according to coming US pharmacopeia chapters. Journal of Pharmaceutical and Biomedical Analysis. 2013;84:209-214

[44] Li G, Schoneker D, Ulman KL, Sturm JJ, Thackery LM, Kauffman JF. Elemental impurities in pharmaceutical excipients. Journal of Pharmaceutical Sciences. 2015;104:4197-4206

[45] Hobbs SE, Olesik JW. Inductively coupled plasma mass spectrometry signal fluctuations due to individual aerosol droplets and vaporizing particles. Analytical Chemistry. 1992;64:274-283

[46] Samantha HT, Horlick G. Matrix-effect observations in inductively coupled plasma mass spectrometry. Journal of Analytical Atomic Spectrometry. 1987;2:745-763 